Tropical Journal of Applied Natural Sciences
Trop. J. Appl. Nat. Sci., 2(1): 106-109 (2017)
ISSN: 2449-2043
https://doi.org/10.25240/TJANS.2017.2.1.18

\title{
Evaluation of Nutrient Composition and Mineral Levels of some Edible Insects
}

\author{
Egbeji, Blessing U.*1, Nwaka, Andrew C. ${ }^{1}$, Ifemeje, Jonathan C. ${ }^{1}$, Olisa, Michael C. ${ }^{2}$ \\ ${ }^{1}$ Department of Biochemistry, Nutrition and Toxicology Unit, Faculty of Natural Sciences, Chukwuemeka Odumegwu Ojukwu University, \\ Anambra State Nigeria. \\ ${ }^{2}$ Deparment of Medical Biochemistry, Chukwuemeka Odumegwu Ojukwu University, Anambra State, Nigeria.
}

*Corresponding author's email: egbejiujunwa@yahoo.com

\begin{abstract}
Varieties of insects are edible to human being and can also be used as feed for animals but detailed nutritional compositions of these insects are not known. Larva of palm weevil, locust and winged termites were analysed for their proximate composition and mineral content. The samples were collected and processed for proximate analysis and mineral composition. The proximate composition was determined using AOAC method while mineral composition was determined using Atomic Absorption Spectrophotometer (AAS). The result of the analysis was analysed statistically using One-way analysis of variance (ANOVA). The result obtained showed that the insects have a desirable amount of protein with locust having the highest composition of $50.42 \%$. The moisture, crude fat and calorific value of the larva of palm weevil was significantly $(\mathrm{p}<0.05)$ higher when compared to that of locust and termite. The mineral content determined showed a significantly $(\mathrm{p}<0.05)$ high level of manganese and copper in termite when compared with locust and larva of palm weevil while zinc and iron were higher in termite and locust respectively. Also, there is appreciable level of calcium in all the insects studied. Generally, the mineral content of the insects studied decreased in the order $\mathrm{Ca}>\mathrm{Mg}>\mathrm{Na}>\mathrm{K}>\mathrm{Zn}>\mathrm{Fe}>\mathrm{Mn}>\mathrm{Cu}$. The mineral content investigated are within Recommended Dietary Allowance (RDA) and the antioxidant minerals may be useful in reduction of oxidative stress. High protein/energy level of the insects may be an advantage in managing protein energy malnutrition in poor developing nation and therefore, consumption of these insects is recommended.
\end{abstract}

Original Research Article

Received: 11th Sept. 2017 Accepted: 8th Oct. 2017

Published: $16^{\text {th }}$ Oct., 2017

\section{Keywords:}

Edible insects;

Proximate composition;

Mineral composition;

Termite,

Nutrient.

\section{INTRODUCTION}

I nsects are important source of nutrients for human being and a wide variety of animals and numerous references to their nutritional value are found across a wide range of scientific disciplines. The UN projected the world population to reach 9.6 billion people in 2050 (United Nations Department of Economic and Social Affairs, Population Division, 2013) which will require increased food and feed outputs. Edible insects are traditionally consumed in many parts of the world (Defoliart, 1992) and are considered as having potential to contribute to the world's food security (Van Huis et al., 2013). It is estimated that at least 2 billion people eat insects on a regular basis (Van Huis et al., 2013), not only because of their nutritive value but also because of their taste (Nonaka, 2009). However, in some urban and western societies, insects are rarely eaten or consumption is even perceived as culturally inappropriate (FAO, 2010 and Van Huis, 2013) and disgusting (Nonaka, 2009).

Insects are considered food with satisfactorily energy and protein content and high contents of a variety of micro nutrients such as copper, iron, manganese, phosphorus, selenium and zinc (Rumpold and Schlüter, 2013). Beside those characteristics that can improve the nutrition status directly, insects also have positive effects on the environment. They play an important role in waste biodegradation and as pollinators in plant reproduction. Furthermore, they have a high feed conversion efficiency and their production is less land-dependent than conventional 
livestock, which makes them resource-saving food and feed, and it is probable that they produce less greenhouse gases and use significantly less water than conventional livestock (Nakagaki and DeFoliart, 1992; FAO, 2010). Finally, increasing the production and consumption of edible insects is suspected to have an impact on livelihood and social conditions. Gathering and farming of insects can be done with a minimal input of technical or capital resources which gives also the poorest members of society a possibility to acquire income (FAO, 2010).

This study is aimed at investigating the nutritional composition of palm weevil larva, locusts and termites with the aim of comparing the nutritional composition and mineral profile among the insects.

\section{MATERIALS AND METHODS}

\section{Sample Collection}

The locusts were collected from grassland field of Maiduguri in Borno State, Nigeria using insect net. Larva of Raffia Palm Weevil was handpicked from Raffia palm in Ihiala, Anambra State of Nigeria and the winged termites were bought from Ogboefere market, Ogbaru in Anambra State of Nigeria. The number of insects collected per individual insect was fifty (50) raffia palm larva and locust and a cup of the winged termites.

\section{Sample Preparation}

The samples were oven-dried at $60-70^{\circ} \mathrm{C}$ for $72 \mathrm{hrs}$. Then the dried specimens were mechanically ground into powder and sieved through a 60-mesh screen while samples for mineral analysis were ground using mortar and pestle.

\section{Sample Analysis}

Crude fat, crude fibre, ash sand moisture contents were analysed by the Association of the Official Analytical Chemists (AOAC, 2006) methods. Nitrogen content was estimated by the AOAC Kjeldahl method. Crude protein was subsequently calculated by multiplying the nitrogen content by a factor of 6.25 . Carbohydrate was calculated by the difference method (summing the value of moisture, ash, crude fat, fiber and crude protein and subtracting the sum from 100). The caloric value was calculated by multiplying the mean values of crude protein, crude fat and total carbohydrate by the At wat factor of 4, 9 and 4 respectively, summing the products and expressing the result in kilocalories per $100 \mathrm{~g}$ sample as reported by Onyeike and Omumbo-Dede, (2002).

The mineral composition of the insects were determined by mixed acid digestion as reported by Ifemeje (2015). The digested samples were analysed for mineral levels using Varian AA240 Atomic Absorption Spectrophotometer according to the method of American Public Health Association (APHA, 1995). The instrument was calibrated by standard solutions treated in the same way as samples. Aldrich provided the analytical standard used. By comparing the peak of the absorbance of standard with that of the test sample, the concentrations of the elements in the test samples were determined.

\section{Method of Data Analysis}

Data were presented as mean $\pm \mathrm{SD}$ of three replicate determinations. Data were analyzed statistically by one way analysis of variance (ANOVA) and means' were compared by the Duncan's multiple range test; significance was accepted at $\mathrm{P} \leq 0.05$.

\section{RESULTS AND DISCUSSION}

In Africa, entomophagy is traditionally and culturally acceptable way by which low income persons supplement the meager protein content of their high carbohydrate diets (Ekop et al. 2009). The larva of the palm weevil, locust and termites are insects that are highly relished food item in Nigeria, especially among the rural populace but it's also currently available in most urban markets of the country. In this study, the proximate composition of these insects were determined.

The result of this study showed that these insects have an appreciable amount of carbohydrate. However, the carbohydrate content was low in comparison with those reported for M. bellicosus (43.3\%) and M. notalensis (42.8\%) (Banjo, et al., 2006). The crude protein content of these insects fall within the protein range of $15-60 \%$ previously reported for various forms of edible insects (Ramos-Elorduy, 1997). This showed that the insects could be used to meet the protein demand of many developing countries.

When the proximate composition of these insects were compared as shown in Table 1, The result showed that there was no significant difference $(p<0.05)$ in the moisture content of locust and termite but the moisture content of palm maggot is significantly higher $(p<0.05)$ when compared to termite and locust. The crude fat content, the crude fiber content and the calorific value of the palm maggot is significantly higher $(\mathrm{P}<0.05)$ than those of the locust and termite. Table 1 also indicated that the protein and ash content of locust is significantly higher $(p<0.05)$ than that of the palm maggot and termites. Larva of Palm weevil has the least amount of crude protein. This could be as a result of high proportion of fat. Fat content is known to be inversely related to crude protein (Cullison and Lowrey, 1987). The result showed high lipid content (crude fat) in larva of palm weevil and termite when compared to locust. The implication of lipid content on comparative feeding is that locust will attract more value by virtue of its lower fat content. This result agrees with Taylor (1975) and Defoliart (1991) that some insects species have high fat content compared to others. The termite and larva of palm weevil with high lipid content will be rich in dietary fats. Dietary fat increases the palatability of food by absorbing and retaining flavour. Hence, the high lipid content observed in larva of palm weevil and termites could have contributed to the reduced need of oil in the preparation of these delicacies. The gross energy value given by these insects depends on the amount of protein, fat, and carbohydrate contents of the insects. All the studied species had high gross energy values, a finding similar to the high caloric content value reported from 78 other species of edible insects (Ramos-Elorduy, 2009). Given the observed high 
lipids, protein and carbohydrate contents of these insects, it could be inferred that the delicacies if adequately promoted, can help in controlling protein energy malnutrition, an imbalance between the supply of protein and energy, and the body's demand for them to ensure optimal growth and function, which is currently ravaging children in developing countries (Okwu et al., 2010).

Consequently, the relatively low percentage moisture content obtained from the insects studied indicated that these insects can be stored for a reasonable period of time without the risk of microbial deterioration and spoilage if properly dehydrated. The higher content of crude fibre in palm maggot and termites could be explained on account of their feeding behaviour (preferring woody plants to grasses). Components of crude fibre are mainly structural carbohydrates which are celluloses and hemi celluloses. Also, high crude fibre content in the insects could be due to the chitin normally found in insects (Akinnawo and Ketiku, 2000). The fibre found in these insects can be used to meet the recommended dietary allowance (RDA) of fibre which is $14 \mathrm{~g}$ per 1000 calories consumed (DRI, 2003). Adequate intake of fibre rich food promotes healthy cholesterol and blood glucose levels. In the presence of an adequate amount of fluid, fibre makes stools larger, softer and easier to pass. The significantly higher level of ash in the termite and locust compared to larva of palm weevil could be explained on account of the fact that the termites feed principally on humus, grass and fungi; locust feeds on grasses too while the larva of palm weevil feed principally on tender foliage.

The result of mineral composition of the three insects studied when compared in Table 2 showed that $\mathrm{Na}, \mathrm{Ca}, \mathrm{Mg}$ and $\mathrm{Zn}$ levels in larva of palm weevil were significantly higher $(\mathrm{P}<0.05)$ than the values in locust and termite while $\mathrm{K}, \mathrm{Mn}$ and $\mathrm{Cu}$ levels in termite were significantly higher $(\mathrm{P}<0.05)$ than the values in locust and larva of palm weevil. Locust were significantly high $(\mathrm{P}<0.05)$ in Fe level when compared to larva of palm weevil and termites.
The mineral composition of the samples shows that the concentration of the mineral varies among the different samples, while there was high concentration of sodium in larva of palm weevil, the concentration of manganese was the lowest. This observation corroborates Okaraonye and Ikewuchi, (2008) who reported that the mineral analysis in larva of palm weevil revealed a very high sodium $(20.29 \mathrm{mg} / 100 \mathrm{~g})$ content with moderate levels of copper and manganese $(2.61 \mathrm{mg} / 100 \mathrm{~g}$ and $2.31 \mathrm{mg} / 100 \mathrm{~g})$ respectively. The termites was found to have high concentrations of calcium, sodium, magnesium and potassium, this corroborates Igwe et al. (2011) who stated that the termite has a fair content $(7.60 \pm 0.33 \%)$, with the major macro minerals being potassium and sodium, while the micro minerals were iron, zinc, manganese and copper. Minerals are known to play important metabolic and physiological roles in the living system. Iron, zinc, copper and manganese strengthen the immune system as antioxidant enzyme cofactors (Talwar et al., 1989). However, the iron in locust and termite cannot meet the RDA of 45mg (DRI, 2003) and so iron needs to be supplemented in this diet because low iron intake has been associated with anaemia. Similarly, magnesium and zinc prevent cardiomyopathy, muscle degeneration, growth retardation, impaired spermatogenesis, immunological dysfunction and bleeding disorder (Chaturvedi et al., 2004) and they are readily available in these insects. There was high concentration of magnesium in the three insects while iron was not found in the raffia palm maggot (Table 2). The copper content of the three insects can supply the recommended minimum daily allowance, which is 0.9 1.91mg (McGilvery and Goldstein, 1983).

\section{CONCLUSION}

The results of this work showed that larvae of palm weevil, locust and winged termites are rich sources of protein, carbohydrates, and minerals and so may be recommended for consumption for economically weaker sections of populations throughout the developing country, most especially in Africa and Asia, to alleviate the problem of protein energy malnutrition.

Table 1: Comparison of the Proximate Composition (\%) of Three Different Edible Insects

\begin{tabular}{llll}
\hline $\begin{array}{l}\text { Proximate } \\
\text { Composition }(\%)\end{array}$ & Larva of Palm weevil & Locust & Termite \\
\hline Moisture & $4.43 \pm 0.15^{\mathrm{a}}$ & $3.81 \pm 0.01^{\mathrm{b}}$ & $3.90 \pm 0.01^{\mathrm{b}}$ \\
Ash & $2.33 \pm 0.01^{\mathrm{c}}$ & $6.24 \pm 0.01^{\mathrm{a}}$ & $4.25 \pm 0.01^{\mathrm{b}}$ \\
Crude fibre & $17.22 \pm 0.01^{\mathrm{a}}$ & $15.65 \pm 0.01^{\mathrm{c}}$ & $16.35 \pm 0.01^{\mathrm{b}}$ \\
Crude fat & $32.13 \pm 0.01^{\mathrm{a}}$ & $19.62 \pm 0.01^{\mathrm{c}}$ & $26.35 \pm 0.01^{\mathrm{b}}$ \\
Crude protein & $37.51 \pm 0.01^{\mathrm{c}}$ & $50.42 \pm 0.01^{\mathrm{a}}$ & $41.70 \pm 0.01^{\mathrm{b}}$ \\
Carbohydrate & $7.42 \pm 0.01^{\mathrm{b}}$ & $4.78 \pm 0.01^{\mathrm{c}}$ & $7.45 \pm 0.01^{\mathrm{a}}$ \\
Calorific value $(\mathrm{Kcal} / 100 \mathrm{~g})$ & $468.89 \pm 0.01^{\mathrm{a}}$ & $397.38 \pm 0.01^{\mathrm{c}}$ & $433.34 \pm 0.01^{\mathrm{b}}$ \\
\hline
\end{tabular}

Values are mean \pm standard deviation of triplicate determination.

Values within the same row bearing the same superscript letters are not significantly different at $\mathrm{P}<0.05$. 
Table 2: Comparison of the Mineral Levels ( $\mu \mathrm{g} / \mathrm{g}$ ) of Three Different Edible Insects

\begin{tabular}{llll}
\hline $\begin{array}{l}\text { Minerals } \\
\boldsymbol{\mu g} / \mathbf{g}\end{array}$ & Larva of Palm Weevil & Locust & Termite \\
\hline $\mathrm{Na}$ & $13.00 \pm 1.00^{\mathrm{a}}$ & $0.31 \pm 0.01^{\mathrm{c}}$ & $9.21 \pm 0.01^{\mathrm{b}}$ \\
$\mathrm{K}$ & $7.90 \pm 0.01^{\mathrm{b}}$ & $0.83 \pm 0.01^{\mathrm{c}}$ & $14.53 \pm 0.02^{\mathrm{a}}$ \\
$\mathrm{Mn}$ & $0.34 \pm 0.01^{\mathrm{c}}$ & $1.01 \pm 0.01^{\mathrm{b}}$ & $10.87 \pm 0.01^{\mathrm{a}}$ \\
$\mathrm{Ca}$ & $32.61 \pm 0.01^{\mathrm{a}}$ & $24.43 \pm 0.01^{\mathrm{c}}$ & $28.31 \pm 0.01^{\mathrm{b}}$ \\
$\mathrm{Cu}$ & $0.81 \pm 0.01^{\mathrm{b}}$ & $0.29 \pm 0.01^{\mathrm{c}}$ & $1.05 \pm 0.01^{\mathrm{a}}$ \\
$\mathrm{Zn}$ & $5.35 \pm 0.01^{\mathrm{a}}$ & $3.73 \pm 0.01^{\mathrm{c}}$ & $4.88 \pm 0.01^{\mathrm{b}}$ \\
$\mathrm{Fe}$ & $0.00 \pm 0.01^{\mathrm{c}}$ & $4.57 \pm 0.01^{\mathrm{a}}$ & $3.64 \pm 0.01^{\mathrm{b}}$ \\
$\mathrm{Mg}$ & $19.75 \pm 0.01^{\mathrm{a}}$ & $19.58 \pm 0.01^{\mathrm{b}}$ & $19.49 \pm 0.01^{\mathrm{c}}$ \\
\hline
\end{tabular}

Values are mean \pm standard deviation of triplicate determination

Values within the same row bearing the same superscript letters are not significantly different at $\mathrm{P}<0.05$.

\section{REFERENCES}

Akinnawo, O. and Ketiku, A.O. (2000). "Chemical composition and fatty acid profile of edible larva of Cirina forda (westwood). Afr. J. Biomed. Res. 3:93-96.

American Public Health Association (1995). Cold - Vapour Atomic Absorption Spectrometric Method, Standard Methods for the Examination of Water and Waste Water, $20^{\text {th }}$ Edition, APHA, AWWA, WEF.

AOAC (2006). Official method of analysis. $18^{\text {th }}$ edition. Revised Washington, DC, USA: Association of Official Analytical Chemists.

Banjo, A.D., Lawal, O.A. and Songonuga, E.A. (2006). "The Nutritional Value of Fourteen Species of Edible Insects in Southwestern Nigeria". Afri J Biotech 5: 298-301.

Chaturvedi, V.C., Shrivastava, R. and Upreti, R.K. (2004). "Viral Infections and Trace Elements: A complex Interaction”. Current Sci. 87: 15361554.

Cullison, A. and Lowrey, R.S. (1987). Feeds and Feeding. $4^{\text {th }}$ edn. PrenticeHall. Inc. New Jersey. P. 645.

Defoliart, G.R. (1992). "Insects as human food". J. Crop Protection, 11:395399. https://doi.org/10.1016/0261-2194(92)90020-6.

Dietary Reference Intakes (2003). Applications in Dietary Planning. National Academy Press. P.51

Ekop K.E., Onigbinde, A.O. and Asia, I.O. (2009). "Pharmaceutical Potentials of the Oils of some Popular Insects Consumed in Southern Nigeria". Afri J Pharm \& Pharmacol 3: 051-057.

FAO Regional Office for Asia and the Pacific. (2010). Forest insects as food: humans bite back: Proceedings of a workshop on Asia-Pacific resources and their potential for development, 19-21 February 2008, Chiang Mai, Thailand. (P. B. Durst, Ed.). Bangkok, Thailand: Food and Agriculture Organization of the United Nations, Regional Office for Asia and the Pacific.

Igwe, C.U., Onwuliri, V.A., Ojiako, A.O. and Arukwe, U. (2011). "Effects of Macrotermes nigeriensis Based Diet on Hepatic and Serum Lipids of Albino Rats". Australian J. Basic \& Appl. Scs. 5: 906-910.

Igwe, C.U., Ujowundu, C.O., Nwaogu, L.A. and Okwu, G.N. (2011). "Chemical Analysis of an Edible African Termite, Macrotermes nigeriensis; a Potential Antidote to Food Security Problem". Biochem. \& Anal. Biochem. 1:105.

Ifemeje, J.C (2015): Effects of Heat Processing On Proximate Composition of Local Leafy Vegetables Consumed In South- East, Nigeria. Inter.J.Sci. Res \& Pub 5(12): 660-665.
Mc Gilvery, R.W. and Goldstein, G.W. (1983). Biochemistry: A Functional Approach $3^{\text {rd }}$ ed., W.B Saunders, Philadelphia. P. 350

Nakagaki, B.J. and DeFoliart, G.R. (1991). "Comparison of diets for massrearing acheta dornesticzs (Orthoptera: Gryllidae) as of food conversion efficiency with values reported for livestock". Journal of $\begin{array}{llll}\text { Economic Entomology, } \quad \mathbf{8 4} & \text { (3): } & \text { 891-896. }\end{array}$ https://doi.org/10.1093/jee/84.3.891.

Nonaka, K. (2009). "Feasting on Insects". Entomological Research, 39 (5): 304-312. https://doi.org/10.1111/j.1748-5967.2009.00240.x

Okaronye, C.C. and Ikewuchi, J.C. (2008). "Rhynchophorus phoenicis (F) Larva Meal: Nutritional Value and Health Implications. Journal of Biological $\quad$ Sciences, $\quad \mathbf{8}: \quad 1221-1225$. https://doi.org/10.3923/jbs.2008.1221.1225

Okwu, G.N., Ilobinso, A.C., Onoh, C.N. and Igwe, C.U. (2010) "Assessment of Protein Energy Malnutrition Among Preschool Children Attending Well Baby Clinic at Federal Medical Centre, Owerri". Intl. J. Biochem. 2: 77-81.

Onyeike, E. N. and Omubo-Dede, T. T. (2002). Effect of heat treatment on the proximate composition, energy values, and levels of some toxicants in African yam bean (Sphenostylis stenocarpa) seed varieties. Plant Foods Hum. Nutr., 57: 223-231. https://doi.org/10.1023/A:1021833516234

Ramos-Elorduy, Julieta (1997). "Insect: A sustainable source of food?" Ecology of food and nutrition 36 (2-4): 247-276.

Ramos-Elorduy, Julieta (2009). "Anthropo-Entomophagy: Cultures, Evolution and Sustainability". Entomological Research, 39 (5): 271288. https://doi.org/10.1111/j.1748-5967.2009.00238.x

Rumpold, B.A. and Schlüter, O.K. (2013). "Nutritional composition and safety aspects of edible insects". Molecular Nutrition \& Food Research, 57 (5): 802-823. https://doi.org/10.1002/mnfr.201200735.

Talwar GP, Srivastava LM, Mudgil KD (1989) Textbook of Biochemistry and Human Biology. Prentice Hall of India Private Limited, India

Taylor, R.L. (1975). Butterflies in my stomach. Santa Barbara, Woodbridge Press. P. 224

United Nations, Department of Economic and Social Affairs, Population Division. (2013). World Population Prospects - The 2012 Revision Key Findings and Advance Tables (Working Paper No. ESA/P/WP.227.). New York.

Van Huis, A. (2013). "Potential of insects as food and feed in assuring food security". Annual Review of Entomology, 58: 563-583.

Van Huis, A., Van Itterbeeck, J., Klunder, H., Mertens, E., Halloran, A. and Vantomme, P. (2013). "Edible insects: Future prospects for food and feed security". Food and Agriculture Organization of the United Nations, Rome.

\section{How to cite this article}

Egbeji, B.U., Nwaka, A.C., Ifemeje, J.C. and Olisa, M.C. (2017). Evaluation of Nutrient Composition and Mineral Levels of some Edible Insects. Tropical Journal of Applied Natural Sciences, 2(1): 106-109. DOI: https://doi.org/10.25240/TJANS.2017.2.1.18. 